\author{
Radosław Kuliniak (iD https://orcid.org/0000-0002-0090-6609 \\ Uniwersytet Wrocławski \\ radoslaw.kuliniak@uwr.edu.pl
}

Mariusz Pandura iD https://orcid.org/0000-0001-5875-2705
Uniwersytet Wrocławski
mariusz.pandura@uwr.edu.pl

\title{
Poeta sam na sam z sobą - dziennik osobisty Romana Witolda Ingardena
}

\section{Poet Confronted with Himself - Personal Journal of Roman Witold Ingarden}

\begin{abstract}
The Ingarden family archive includes the diary of Roman Witold Ingarden, over 400 pages long. This personal document is not completely unknown in Polish specialist literature dealing with the life and work of the phenomenologist. As an author of an autobiographical work, Ingarden was certainly not an exception in his times. At the turn of the $19^{\text {th }}$ and the $20^{\text {th }}$ century, many people wrote diaries and other life narratives. It is worth noting that personal journals (some later published and some still available only in handwritten form) were written by Kazimierz Twardowski, Władysław Tatarkiewicz, and other Polish philosophers. It was also enormously popular to write letters and poetry bearing autobiographical traces. It should be noted that the text analysed in the article was not originally created as an autobiographical document of a philosopher, but as an account of the life of an aspiring artist. Ingarden was a poet for a large part of his life and continued to write poetry even after the Second World War.
\end{abstract}

Keywords: Roman Witold Ingarden, diary

Streszczenie: W Archiwum Rodziny Ingardenów zachował się liczący ponad 400 stron pamiętnik Romana Witolda Ingardena. Ten osobisty dokument nie jest zupełnie nieznany w polskiej literaturze fachowej na temat życia i twórczości fenomenologa. Ingarden jako autor dzieła autobiograficznego nie był z pewnością wyjątkiem w swoich czasach. Na przełomie XIX i XX wieku wiele osób pisało pamiętniki i inne narracje życiowe. Warto wspomnieć, że osobiste dzienniki (później opublikowane lub pozostające do dziś w formie rękopiśmiennej) tworzyli Kazimierz Twardowski, Władysław Tatarkiewicz i inni polscy filozofowie. Ponadto niezwykle popularna była praktyka pisania listów, a także poezji noszącej znamiona autobiograficzne. Należy zaznaczyć, że tekst ten nie powstał pierwotnie jako dokument autobiograficzny filozofa, ale jako zapis życia niedoszłego artysty. Ingarden był poetą przez dużą część swojego życia i pisał wiersze również po drugiej wojnie światowej. Słowa kluczowe: Roman Witold Ingarden, dziennik osobisty 
W Archiwum Rodzinnym Ingardenów zachował się obszerny dziennik osobisty Romana Witolda Ingardena, obejmujący w swojej podstawowej partii ponad 400 stron $^{1}$. Ten dokument osobisty nie jest zupełnie nieznany w polskiej literaturze specjalistycznej dotyczącej życia i twórczości fenomenologa. Za zgodą syna filozofa - profesora Romana Stanisława Ingardena - z tekstu miała możliwość skorzystać Zofia Majewska, przygotowując swój zarys biograficzny życia filozofa. Opublikowała ona tam kilkanaście passusów z dokumentu osobistego, pochodzących w większości z roku $1909^{2}$. Krótkie partie diarystyczne z lat trzydziestych XX wieku zostały wydane przez Ryszarda Jadczaka, ponownie za zgodą Romana Stanisława Ingardena, w 1997 roku w toruńskim „Przeglądzie Artystyczno-Literackim"3. W dwa lata później wybór ten został przedrukowany w zeszycie „Kwartalnika Filozoficznego”, poświęconemu fenomenologowi ${ }^{4}$. Liczne passusy z tekstu dziennika, udostępnionego przez profesora Krzysztofa Ingardena, zostały również opublikowane przez Radosława Kuliniaka i Mariusza Pandurę w pierwszej części ich obszernej, dwutomowej biografii ${ }^{5}$.

Fenomenolog nie był w swojej twórczości autobiograficznej wyjątkiem w swoich czasach. Na przełomie XIX i XX wieku dzienniki, pamiętniki i inne dokumenty osobiste pisało wiele osób. Warto zwrócić uwagę, że dzienniki (dziś opublikowane lub pozostające nadal w rękopisach) wyszły spod pióra między innymi Kazimierza Twardowskiego, Władysława Tatarkiewicza i Henryka Elzenberga ${ }^{6}$. Powszechnie pisano listy, tworzona była nacechowana piętnem autobiograficznym poezja. Trzeba przy tym podkreślić, że tekst nie powstawał pierwotnie jako dokument autobiograficzny filozofa, lecz jako zapis życia poety, którym Ingarden pozostawał przez dużą część życia, od pierwszego dziesięciolecia XX wieku, kontynuując swoją twórczość liryczną nawet jeszcze po drugiej wojnie światowej.

1 Autorzy dziękują Profesorowi Krzysztofowi Ingardenowi, z którego inicjatywy podjęli się prac nad diariuszem Romana Witolda Ingardena. Jego też uprzejmości zawdzięczamy możliwość opublikowania w niniejszym zeszycie najwcześniejszej partii diariusza.

2 Zob. Z. Majewska, Ksiażeczka o Ingardenie. Szkic biograficzny, Lublin 1995, s. 14-19, 24-25, s. 27, przyp. 2, 44-45.

3 Zob. R.W. Ingarden, $Z$ „Dziennika”, „PAL. Przegląd Artystyczno-Literacki” 1997, nr 12, s. $24-28$.

${ }^{4}$ Zob. tenże, $Z$ „Dziennika”, „Kwartalnik Filozoficzny” 1999 , t. 27, z. 2, s. 201-209.

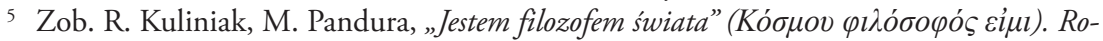
man Witold Ingarden (1893-1970). Część pierwsza: lata 1893-1938, Kęty 2019.

6 Zob. K. Twardowski, Dzienniki mtodzieńcze (1881-1887). Uzupetnione "Dziennikiem” Marii Gąsowskiej (1881), wierszami wiedeńskimi (1882) oraz korespondencja z rodzicami (18821893), Józefem Krypiakiewiczem (1885-1886) i Wojciechem Dzieduszyckim (1885-1891), oprac. A. Brożek, Warszawa 2013; tenże, Dzienniki. Cz. 1, 1915-1927, oprac. R. Jadczak, WarszawaToruń 1997; tenże, Dzienniki. Cz. 2, 1928-1936, oprac. R. Jadczak, Warszawa-Toruń 1997; W. Tatarkiewicz, Dzienniki, t. 1: Lata 1944-1960, oprac. R. Kuliniak, D. Leszczyna, M. Pandura, Ł. Ratajczak, Kęty 2019 (tom drugi ukaże się pod koniec 2021 roku); H. Elzenberg, Ktopot z istnieniem. Aforyzmy w porzadku czasu, wyd. popr. i uzup., Toruń 2002. 
Majewska, która jako pierwsza opublikowała pewną ilość passusów z tego dokumentu osobistego, cytuje go jako Pamiętnik, traktując nazwę własną jako tytuł'. Sam autor określał dokument osobisty wielokrotnie jako „pamiętnik”, nie traktując jednak tej nazwy jako tytuł, lecz jako rzeczownik pospolity. Wskazać trzeba jednoznacznie, że ten tekst jest dziennikiem osobistym. W skład jego struktury wchodzą chronologicznie uporządkowane zapisy autobiograficzne z wyraźnie uwypukloną datacją. Autor dokumentu w kilka lat po rozpoczęciu jego prowadzenia sam miał wątpliwości, czy nazwa „pamiętnik” jest właściwa dla jego dzieła. Przykładowo, gdy w 1916 roku po raz kolejny wrócił do pisania notek autobiograficznych, rozważał, jak określać dokument: jako „pamiętnik” czy raczej „dziennik”. Do tej drugiej nazwy wówczas się skłaniał.

W początkowych latach swego istnienia diariusz Ingardena niewątpliwie nie nosił tytułu. Istnieje jednak możliwość, że tytuł ten został mu w późniejszych latach nadany przez fenomenologa. W dokumentacji przechowywanej w Archiwum Rodzinnym Ingardenów znajdujemy brązową kartonową teczkę wyprodukowaną w Fabryce Niemeńskiej z nadrukiem „»Expromptum “A”. Teczka tak została podpisana ręką Ingardena „Sam na sam z sobą. Roman Ingarden”. Nazwisko i imię jest zapisane zwykłym, wielokrotnie poświadczonym w źródłach pisanym kursywą podpisem fenomenologa, jednakże sam tytuł jest wykaligrafowany. Obecnie w teczce przechowywane są między innymi maszynopisy wierszy autorstwa Ingardena, a także wiersze Czesława Miłosza, Rainera Marii Rilkego, Thomasa Stearnsa Eliota, część niedokończonej powieści autorstwa fenomenologa pt. Zetlate dusze ${ }^{9}$. Teczka jest rozmiarów A4, podobnie jak część kart w niej przechowywanych.

Powstaje pytanie, do czego odnosi się tytuł odnotowany na teczce. Najbardziej prawdopodobne są dwie możliwości: 1) tytuł Sam na sam z sobą odnosi się do zbioru wierszy fenomenologa, który chciał on, bezskutecznie, opublikować w połowie lat dwudziestych XX wieku, 2) tytuł Sam na sam z soba został przez filozofa nadany wtórnie jego diariuszowi. Według nas nie jest niemożliwe, że tytuł ten odnosi się do diariusza. We wspomnianej teczce przechowywane były materiały mniejsze niż A4, w tym też takie, które odpowiadają rozmiarowi diariusza. Wskazują na to ślady na przedniej karcie teczki. Możliwe, iż tekst różnych partii diariusza był przechowywany pierwotnie w owej teczce wraz z twórczością liryczną. Niewątpliwie wszakże zawartość teczki była w późniejszym czasie uzupełniana, w ten sposób chociażby trafiły do niej z całą pewnością wtórnie wiersz Forum Romanum z 1946 roku i maszynopis Zetlatych dusz. Partie diariusza, a także wyodrębnione zeszyty wierszy z kolei, jeśli znajdowały

7 Zob. Z. Majewska, dz. cyt., s. 15-16.

8 Zob. R.W. Ingarden, [Zeszyt czarny (1): dziennik osobisty (1909-1916)], Archiwum Rodzinne Ingardenów, s. luźna (nienumerowana), zapis z 19 kwietnia 1916 roku.

9 Por. D. Ulicka, Granice literatury i pogranicza literaturoznawstwa. Fenomenologia Romana Ingardena w świetle filozofii lingwistycznej, Warszawa 1999, s. 179. 
się uprzednio w teczce, zostały z niej wyodrębnione, jako iż były częściej używane, czy to jeszcze za życia Ingardena w trakcie jednej z wielu rewizji dokonywanych przez niego samego, czy to już po jego śmierci.

Ingarden rozpoczą tworzenie Dziennika w 1909 roku. Pierwsza nota datowana jest na przeddzień jego szesnastych urodzin, 4 lutego. Zapisy prowadził w zeszytach i kartkach pochodzących z zeszytów. Kontynuował jego pisanie, z przerwami, do końca nauki w gimnazjum, a później w okresie studiów we Lwowie, Getyndze, Wiedniu i Fryburgu. Systematycznie zapisy prowadzone były do 13 marca 1912 roku. Noty z późniejszych lat pisane były jedynie w niektórych okresach życia i miały zupełne inny charakter niż te z okresu młodzieńczego ${ }^{10}$.

Spośród wielu spraw, które toczyły się w życiu Ingardena w głównym okresie pisania dziennika osobistego, diarysta koncentrował się jedynie na wybranych. Przy tym duża część jego wypowiedzi zdominowana jest przez funkcję autorefleksyjną ${ }^{11}$. Ingarden, zwłaszcza młody Ingarden, przez praktykę diarystyczną analizuje siebie, swoją psychikę, uczucia, postępowanie. Jego autorefleksja jest połączona z cechą, która jest charakterystyczna dla wielu autorów dzienników osobistych piszących codziennie, czyli z „,niesłychanym egocentryzmem diarysty" ${ }^{12}$. Egocentryzm ten dominuje w głównej, wcześniejszej części tego dokumentu osobistego, i chociaż w końcowych partiach tekstu przygasa, można stwierdzić, iż stanowi jeden z fundamentalnych składników diarystyki Ingardena ${ }^{13}$. Jako istotny temat rozważań jawi się także jego bogata twórczość poetycka. Przyszły fenomenolog rozprawia o pisaniu przez siebie wierszy, problemach, które utrudniają mu twórczość, i warunkach, które ją ułatwiają. Wielokrotnie pojawia się wątek talentu, co do którego posiadania Ingarden ma większe lub mniejsze wątpliwości. Jednakże równie ważnym zagadnieniem, poruszanym w diariuszu, są kontakty autora z Laurą Baranowską. Dzieje wieloletniej znajomości Ingardena i Baranowskiej, przeradzającej się w uczucie raz z jednej, raz z drugiej strony, przewijają się przez diariusz wielokrotnie. Istotny moment stanowiła tu cezura porzucenia przebywającego we Fryburgu Ingardena przez Baranowską i jej ponownego zbliżenia się do Chmielińskiego przebywającego u jej boku w Wiedniu. Zerwanie z Baranowską po jej ślubie z Chmielińskim stanowiło dla Ingardena cezurę w jego życiu. Oznaczało zakończenie okresu młodzieńczego i wkroczenie w życie dorosłe. Podobnie diariusz, rozpoczęty w wieku szesnastu lat, w momencie gdy nastąpił kryzys w relacjach fenomenologa z Baranowską, przestał być dla autora wygodnym

${ }^{10}$ Zob. R.W. Ingarden, [Zeszyt czarny (1): dziennik osobisty (1909-1916)], dz. cyt., wszędzie. Por. Z. Majewska, dz. cyt., s. 15.

${ }^{11}$ Zob. Ph. Lejeune, Jak kończą się dzienniki, tłum. A. Karpowicz [w:] tegoż, „Drogi zeszycie...”, „drogi ekranie...”. O dziennikach osobistych, oprac. P. Rodak, Warszawa 2010, s. 98.

${ }^{12}$ Zob. R. Zimand, Diarysta Stefan Ż., Wrocław-Warszawa-Kraków 1990, s. 72-73.

${ }^{13}$ Zob. tamże, s. 73. 
narzędziem ekspresji i elementem jego niemal codziennej praktyki. Ostatnie zapisy w głównej partii dziennika datowane są na 1916 rok. Potem nastąpiła przerwa w pisaniu. Wraz z ostatecznym odejściem Lor, jak wielokrotnie nazywał Baranowską w dzienniku i korespondencji, przez dłuższy czas Ingarden nie widział sensu kontynuowania zapisków. Porzucił wówczas mrzonki młodzieńczej miłości i wkroczył już jednoznacznie na drogę fenomenologii.

Diarysta, oczywiście, dobierał wydarzenia uznane za godne opisania w dzienniku osobistym. Poza jego horyzontem pozostawały liczne ważne zdarzenia z jego życia, które zostały odnotowane w innych źródłach i skrzętnie spisane przez biografów. Nie dziwi to, gdyż, zgodnie ze słowami Philippa Lejeune’a, dziennik osobisty jest jak koronka utkana ze świata przeżywanego (Lebenswelt), która więcej pomija w swoich pustych obszarach, niż przekazuje w splotach ${ }^{14}$.

Tekst jest rozbity na różne zeszyty. Podstawowa, najwcześniejsza część dziennika, rozpoczęta w lutym 1909 roku, jest obecnie przechowywana w okładce pochodzącej z kontynuacji tekstu. Na okładce tej zachował się zapis diarysty: „Ingarden Roman. [1]910 r. 21. IX. -”. Tekst podlegał także innym mechanicznym modyfikacjom. Pewne partie głównej części nie zachowały się. Tekst w niektórych miejscach jest wymieszany, a wprowadzona numeracja gdzieniegdzie nie jest dokładna ani jednorodna.

Pierwotnie Ingarden dążył do tego, by rejestrować poszczególne aspekty swojej działalności osobno. Noty diarystyczne były prowadzone w odrębnych zeszytach, twórczość poetycka w innych (oznaczonych kolejnymi rzymskimi cyframi $)^{15}$, korespondencja, zdominowana w pierwszym okresie przez listy do ukochanej Laury Baranowskiej, była wysyłana do adresatów, a listy zwrotne przechowywane poza zeszytami diarystycznymi i lirycznymi. W późniejszym czasie dochodziło jednak do przemieszania się tych trzech aspektów działalności. Wiersze odnotowywane są w kolejności powstawania i zostają opatrzone dziennymi datami, jak gdyby stanowiły kolejne noty w diariuszu. Jawią się, zgodnie z formułą Philippe’a Lejeune’a, jako „seria datowanych śladów”" ${ }^{16}$. Wielokrotnie rejestrowane są wówczas oprócz daty także miejsce powstania oraz osoba, niejednokrotnie też adresat wiersza. Wiersze w takich wypadkach zaczynają przypominać korespondencję, na przykład:

„Panu Józefowi Chmielińskiemu

(...) [gtówna treść wiersza]

Kraków, 20 III 1914 r."

${ }^{14}$ Zob. Ph. Lejeune, Koronka. Dziennik jako seria datowanych śladów, tłum. M. Rodak, P. Rodak, „Pamiętnik Literacki” 2006, t. 97, z. 4, s. 23.

${ }^{15}$ Zob. R.W. Ingarden i in., [Zeszyt brązowy: „Zeszyt II., r. 1910”-poezja (Kótko Literackiemateriaty), autorzy: J. Chmieliński, J. Damm, B. Gottlieb, R.W. Ingarden, A. Müller, J. Nartowski], Archiwum Rodzinne Ingardenów; tenże, [Zeszyt niebieski: poezja (1911)], Archiwum Rodzinne Ingardenów.

${ }^{16}$ Zob. Ph. Lejeune, Koronka..., dz. cyt., s. 21. 
Z kolei niektóre noty diarystyczne albo przekazują treść niewysłanych listów do Laury Baranowskiej, albo imitują taką korespondencję.

Pojawiają się również wplecione $\mathrm{w}$ tekst przedmioty pochodzące „z zewnątrz", umieszczane w zeszytach: są to zwłaszcza wycięte fragmenty z dzienników lwowskich, zawierające teksty wierszy, które udało się Ingardenowi i jego najbliższemu przyjacielowi, Janowi Chmielińskiemu, opublikować. Zostały one wklejone do zeszytów, gdzieniegdzie jedynie umieszczone pomiędzy stronami, bez wklejenia. Podobnie pomiędzy kartami można odnaleźć także nietekstowe elementy dziennika: liście czy kwiaty. Gdzieniegdzie dziennik rejestruje tylko ślady ich wcześniejszego tam przechowywania. Takie nietekstowe elementy biologiczne znajdujemy też w zachowanych z owego czasu listach Laury Baranowskiej do Romana Witolda Ingardena ${ }^{17}$. Zeszyty noszą ślady późniejszych rewizji, przy czym niektóre wiersze zostały wycięte i usunięte z głównego ciągu, można więc podejrzewać, że miejsca puste powstały w wyniku działań samego diarysty w konsekwencji dokonanej po latach korekty ${ }^{18}$.

Najmocniej treści diarystyczne z lirycznymi oraz innymi zostały splecione w czarnym zeszycie zainicjowanym 5 listopada 1915 roku $^{19}$. W nim partie liryczne (datowane), diarystyczne $\mathrm{i}$ inne są $\mathrm{z}$ sobą przemieszane $\mathrm{w}$ jednym ciągu chronologicznym, przy czym partie liryczne noszą silne piętno autobiograficzne. Zeszyt rozpoczyna się od wiersza Żegnajcie mi... datowanego na 5 listopada 1915 roku. Po nim pojawiają się cztery utwory liryczne, a dalej tekst prozatorski $Z$ poezyi prozq z 27 listopada 1915 roku. Potem występują utwory pisane w Getyndze: wiersz z 1916 roku po polsku oraz utwór prozatorski po niemiecku. Po kolejnych lirykach pisanych po polsku w Getyndze i Fryburgu następuje ośmiostronicowa partia o charakterze diarystycznym, datowana na 5 sierpnia 1916 roku. Po niej widnieją wiersze, do których dołączona jest partia diarystyczna od 25 października do 17 listopada 1916 roku. Dalej są wiersze z 1917 roku zapisane w samym zeszycie i na luźnych kartach tam przechowywanych. Bezpośrednio po nich w zeszycie zanotowano wiersze z lat 1925-1928. Po nich Ingarden kontynuował partię diarystyczną od 11 listopada 1932 do 2 lutego 1934 roku. Dołączona do niej jest krótka, dwustronicowa, nota diarystyczna z 24 listopada 1934 roku. Kolejno pojawia się dwudziestopięciostronicowy

${ }^{17} \mathrm{O}$ ile dysponujemy w pewnej mierze możliwościami technicznymi przynajmniej częściowego oddania takich nietekstowych elementów w druku. Ale jak oddać na przykład zapach kart lub innych elementów składowych diariusza?

${ }^{18} \mathrm{O}$ powstawaniu miejsc pustych w dziennikach osobistych w wyniku celowego działania diarysty zob. wartościowe uwagi Pawła Rodaka w: tegoż, Puste miejsca $w$ dzienniku Marii Dabrowskiej [w:] (Nie)obecność. Pominięcia i przemilczenia w narracjach XX wieku, red. H. Gosk, B. Karwowska, Warszawa 2008, s. 472-478.

${ }^{19}$ Zob. R.W. Ingarden, [Zeszyt czarny (2): poezja, dziennik osobisty, wyktad z historii filozofii], Archiwum Rodzinne Ingardenów. 
tekst autobiograficzny Dzieje mojej „kariery uniwersyteckiej" ${ }^{20}$, datowany pierwotnie przez fenomenologa na październik 1933 roku, jednakże pisany aż do 18 grudnia 1933 roku. Po nim następuje dwudziestoczterostronicowy tekst pamiętnikarski „Sprawa II. Gimnazjum”. Nie został datowany przez Ingardena, lecz na podstawie informacji znajdujących się w nim można ustalić, iż powstał on kilka lat po 1932 roku, a z całą pewnością po listopadzie 1933 roku. Był przeznaczony pierwotnie jedynie dla żony filozofa i jego synów. Po „Sprawie II. Gimnazjum" następuje w zeszycie ośmiostronicowy tekst Dlaczego pisatem po niemiecku ${ }^{21}$, datowany na lato 1942 roku. Od końca zeszytu zapisane są w przeciwnym kierunku notatki Ingardena z wykładu z historii filozofii. Jedna ze stron zawiera spis treści obejmujący jedynie wiersze występujące w zeszycie, z podziałem na lata powstania. Poszczególne partie zeszytu były notowane różnymi kolorami atramentu, niektóre pismem bardziej starannym, inne mniej. Widoczna jest ewolucja charakteru pisma autora od początkowych partii do końcowych. Zauważalne są również ślady rewizji i poprawek, zresztą stosunkowo nielicznych.

Cały tekst był wielokrotnie przez Ingardena w późniejszych latach rewidowany. Na podstawie dat podanych w uwagach uzupełniających można datować niektóre z tych rewizji, są one też wzmiankowane w dzienniku. Ingarden wracał do tekstu już pół roku po rozpoczęciu notatek. Wielokrotnie analizował krytycznie zapiski z poprzednich miesięcy i starał się uchwycić zmiany, które zachodziły w jego psychice. Początkowo jedynie odczytywał zapisy z poprzednich dni czy nawet dłuższe partie, ale nie nanosił dodatkowych uwag. Dopiero w późniejszych latach, zwłaszcza po wyjeździe na studia zagraniczne, a także w latach trzydziestych XX wieku Ingarden podczas lektury wielokrotnie opatrywał dziennik osobisty uwagami, nierzadko bardzo krytycznymi.

Jak wynika z analizy zawartości czarnego zeszytu, jeden z momentów, gdy Ingarden powrócił do pisania dziennika osobistego, nastąpił w latach trzydziestych, gdy fenomenolog zbliżał się do swoich czterdziestych urodzin. Po okresie błąkania się za chlebem w Lublinie, Warszawie i Toruniu wrócił na łono lwowskiej Semper Fidelis i tamtejszej Alma Mater. Ingarden odnotowywał wówczas nieliczne wydarzenia ze swojego życia: napotkane osoby, nieznośną postawę Kazimierza Ajdukiewicza. Zapał kontynuowania dziennika nie trwał przez dwa lata. Wystarczył jednak na to, by jeszcze raz przejrzeć zapisy i dokonać kolejnych krytycznych adnotacji. Pojawił się także kilkustronicowy wstęp do diariusza, który podobnie sceptycznie odnosił się do niekiedy naiwnej postawy młodzieńca sprzed lat.

${ }^{20}$ Zob. tenże, Dzieje mojej „kariery uniwersyteckiej”, oprac. R. Jadczak, „Kwartalnik Filozoficzny" 1999 , t. 27, z. 2, s. 183-201.

${ }^{21}$ Zob. tenże, Dlaczego pisatem po niemiecku, oprac. R. Jadczak, „PAL. Przegląd Artystyczno-Literacki" 1997, nr 9, s. 6-9. 
II wojna światowa stanowiła dla Ingardena także ważną cezurę w kontynuowaniu diariusza. Prowadzenie dziennika osobistego zarówno w czasie okupacji radzieckiej, jak i okupacji niemieckiej groziło poważnymi konsekwencjami nie tylko samemu fenomenologowi, który zaangażował się w tajną edukację uniwersytecką ${ }^{22}$ i niezgodne $\mathrm{z}$ radzieckim i niemieckim prawem działania mające na celu ratowanie swoich przyjaciół (Władysława Bednarowskiego, Ostapa Ortwina ${ }^{23}$. Mogły też stanowić zagrożenie dla tych z jego bliskich, których miejsce pobytu przez wiele lat było nieznane (siostry Jadwigi Ingarden, syna Jerzego Ingardena ${ }^{24}$. Wreszcie należy wspomnieć o znacznie głębszym zaangażowaniu w działalność konspiracyjną syna - Romana Stanisława i bliskiej znajomej - Izydory Dąmbskiej, która za swoją działalność została w późniejszych latach odznaczona Krzyżem Armii Krajowej ${ }^{25}$. Informacje zanotowane w dzienniku osobistym Ingardena w okresie wojny mogły stanowić zagrożenie dla jego otoczenia. Nie wiemy też, czy Ingarden miał wówczas bezpośredni dostęp do swojego diariusza. Można raczej przypuszczać, że podzielił on los znacznej części rękopisów fenomenologa i został gdzieś złożony do przechowania.

Powstaje przy tym jeszcze pytanie o kompletność zapisów. Duża część diariusza się zachowała. Paginacja, wprowadzona przez fenomenologa, wskazuje, że przynajmniej część dotycząca okresu młodzieńczego zachowana jest w większości. Brak jest niestety partii około trzydziestu kart pod koniec trzeciej setki. Nie wiemy też, jaka część z późniejszych zapisów, nie ocalała. Jak już wspomniano, dziennik przetrwał okres, gdy nie było zbyt bezpieczne przechowywanie zapisków dotyczące bieżących wydarzeń oraz bliskiej przeszłości. Nie wiemy, czy takie zapiski istniały, a jeżeli tak, to, czy zostały zniszczone. Jednak w spuściźnie fenomenologa, z której większością zapoznaliśmy się szczegółowo, nie znaleźliśmy informacji, że taka kontynuacja dziennika istniała.

Niezależnie od wydarzeń z drugiej wojny światowej należy zauważyć, że wraz z powstawaniem kolejnych prac naukowych praktyka diarystyka Ingardena coraz bardziej zanikała, dominować zaczęły inne praktyki piśmienne fenomenologa ${ }^{26}$.

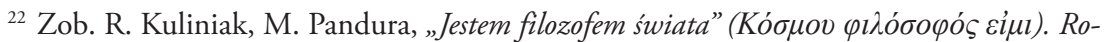
man Witold Ingarden (1893-1970). Część druga: lata 1939-1970, Kęty 2020, s. 106-107.

${ }^{23}$ Zob. tamże, s. 84-85, 111-112.

${ }^{24}$ Zob. tamże, s. 107, 111, 121, 118, 186-187.

${ }^{25}$ Zob. List Romana Stanisława Ingardena do Jerzego Węgierskiego, Toruń, 9 stycznia 1985 roku, Biblioteka Zakładu Narodowego im. Ossolińskich, sygn. rps 16594/II, k. 482; List Romana Stanisława Ingardena do Jerzego Węgierskiego, Toruń, 22 stycznia 1985 roku, Biblioteka Zakładu Narodowego im. Ossolińskich, sygn. rps 16594/II, k. 483-484; J. Perzanowski, Izydora Dąmbska filozof nieztomny [w:] Izydora Dąmbska 1904-1983. Materiaty z sympozjum „Non est necesse vivere, necesse est philosophari”, Kraków, 18-19 grudnia 1998 r., oprac. J. Perzanowski, Kraków 2001, s. 21; R. Kuliniak, M. Pandura, "Jestem filozofem świata”..., Czesść druga..., dz. cyt., Kęty 2020, s. 107.

${ }^{26}$ O postrzeganiu dziennika jako praktyki piśmiennej zob. P. Rodak, Dziennik osobisty jako praktyka piśmienna: dziatanie, materialność, tekst [w:] Antropologia pisma. Od teorii do praktyki, red. Ph. Artières, P. Rodak, Warszawa 2010, s. 178-179. 
Podobny proces powoli zaczynał ograniczać jego twórczość poetycką, ostatecznie prowadząc do jej zaprzestania. Pisanie wierszy było zastępowane przez coraz bardziej teoretyczne rozważania nad estetyką i teorią literatury. Poeta stawał się naukowcem. Dziennik osobisty stopniowo wypierany był przez teksty autobiograficzne, takie jak Dzieje mojej „kariery uniwersyteckiej”, „Sprawa II. Gimnazjum", Dlaczego pisatem po niemiecku, Wspomnienia z Getyngi ${ }^{27}$, Sprawozdanie $z$ dziatalności w Uniwersytecie Jagiellońskim i wspomnienia z tego czasu ${ }^{28}$. Rolę tę przejęły także przeznaczone do natychmiastowej publikacji teksty wspomnieniowe, na przykład komentarz Ingardena do jego korespondencji z Edmundem Husserlem ${ }^{29}$. Chociaż jednak Ingarden w późniejszych latach swojego życia zarzucił pisanie dziennika osobistego oraz twórczość poetycką, pozostał wierny innemu sposobowi autoekspresji: korespondencji ${ }^{30}$. Pierwotnie rozpoczęta na dużą skalę z Laurą Baranowską ${ }^{31}$ prowadzona była przez Ingardena w późniejszym czasie z wieloma osobami i kontynuowana aż do końca życia, tak iż niektóre listy przychodziły na nazwisko fenomenologa jeszcze po jego śmierci.

\section{Bibliografia}

Elzenberg H., Ktopot z istnieniem. Aforyzmy w porzadku czasu, wyd. popr. i uzup., Toruń 2002.

Husserl E., Briefe an Roman Ingarden mit Erläuterungen und Erinnerungen an Husserl, red. R. Ingarden, Den Haag 1968.

Ingarden R.W., Dlaczego pisatem po niemiecku, oprac. R. Jadczak, „PAL. Przegląd Artystyczno-Literacki” 1997, nr 9.

27 Zob. R.W. Ingarden, Wspomnienia z Getyngi, oprac. R. Jadczak, „PAL. Przegląd Artystyczno-Literacki” 1998, nr 5/6, s. 11-18.

${ }^{28}$ Zob. tenże, Sprawozdanie z dziatalności w Uniwersytecie Jagiellońskim i wspomnienia z tego czasu, oprac. J. Perzanowski, „Kwartalnik Filozoficzny” 1999, t. 27, z. 2, s. 216-228.

${ }^{29}$ Zob. E. Husserl, Briefe an Roman Ingarden mit Erläuterungen und Erinnerungen an Husserl, red. R. Ingarden, Den Haag 1968.

${ }^{30}$ Zob. tamże; Spór o prawdę istnienia. Listy Edith Stein do Romana Ingardena, tłum. M. Klentak-Zabłocka, A. Wajs, Kraków-Warszawa 1994; Romana Ingardena spojrzenie na Toruń ( $z$ listów do K. Twardowskiego), oprac. R. Jadczak, „Przegląd Artystyczno-Literacki” 1995, nr 6, s. 24-25; Listy Romana Ingardena do Ostapa Ortwina (Oskara Katzenellenbogena), oprac. S. Ukrainiec, „Pamiętnik Literacki” 1999, t. 90, z. 1, s. 187-195; S.I. Witkiewicz, R. Ingarden, Korespondencja filozoficzna, oprac. B. Michalski, Warszawa 2002; Korespondencja Romana Witolda Ingardena z Kazimierzem Twardowskim, oprac. R. Kuliniak, D. Leszczyna, M. Pandura, Kęty 2016; Korespondencja Romana Witolda Ingardena. Z dziejów „Studia Philosophica. Commentari Societatis Philosophicae Polonorum”, oprac. R. Kuliniak, D. Leszczyna, M. Pandura, Ł. Ratajczak, Kęty 2018; Korespondencja Izydory Dąmbskiej z Romanem Witoldem Ingardenem, oprac. R. Kuliniak, D. Leszczyna, M. Pandura, Ł. Ratajczak, Kęty 2018.

${ }^{31}$ Zob. Korespondencja Laury Baranowskiej (Chmielińskiej) z Romanem Witoldem Ingardenem, Archiwum Rodzinne Ingardenów. 
Ingarden R.W., Dzieje mojej „kariery uniwersyteckiej”, oprac. R. Jadczak, „Kwartalnik Filozoficzny" 1999, t. 27, z. 2.

Ingarden R.W., Sprawozdanie z dziatalności w Uniwersytecie Jagiellońskim i wspomnienia z tego czasu, oprac. J. Perzanowski, „Kwartalnik Filozoficzny” 1999, t. 27 , z. 2.

Ingarden R.W., Wspomnienia z Getyngi, oprac. R. Jadczak, „PAL. Przegląd Artystyczno-Literacki" 1998, nr 5/6.

Ingarden R.W., $Z$ „Dziennika”, oprac. R. Jadczak, „PAL. Przegląd Artystyczno-Literacki” 1997, nr 12.

Ingarden R.W., $Z$ „Dziennika”, oprac. R. Jadczak, „Kwartalnik Filozoficzny” 1999, t. 27 , z. 2.

Ingarden R.W., [Zeszyt czarny (1): „- dziennik osobisty (1909-1916)], Archiwum Rodzinne Ingardenów.

Ingarden R.W., [Zeszyt czarny (2): poezja, dziennik osobisty, wyktad z historii filozofii], Archiwum Rodzinne Ingardenów.

Ingarden R.W., [Zeszyt niebieski: poezja (1911)], Archiwum Rodzinne Ingardenów. Ingarden R.W. i in., [Zeszyt brązowy: „Zeszyt II., r. 1910”-poezja (Kótko Literackie - materiaty), autorzy: J. Chmieliński, J. Damm, B. Gottlieb, R.W. Ingarden, A. Müller, J. Nartowski], Archiwum Rodzinne Ingardenów.

Korespondencja Izydory Dąmbskiej z Romanem Witoldem Ingardenem, oprac. R. Kuliniak, D. Leszczyna, M. Pandura, Ł. Ratajczak, Kęty 2018.

Korespondencja Laury Baranowskiej (Chmielińskiej) z Romanem Witoldem Ingardenem, Archiwum Rodzinne Ingardenów.

Korespondencja Romana Witolda Ingardena. Z dziejów „Studia Philosophica. Commentari Societatis Philosophicae Polonorum", oprac. R. Kuliniak, D. Leszczyna, M. Pandura, Ł. Ratajczak, Kęty 2018.

Korespondencja Romana Witolda Ingardena z Kazimierzem Twardowskim, oprac. R. Kuliniak, D. Leszczyna, M. Pandura, Kęty 2016.

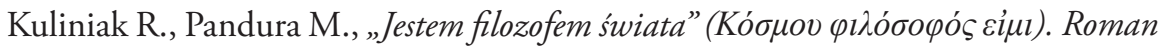
Witold Ingarden (1893-1970). Cześśc pierwsza: lata 1893-1938, Kęty 2019.

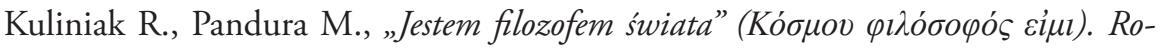
man Witold Ingarden (1893-1970). Część druga: lata 1939-1970, Kęty 2020.

Lejeune Ph.,Jakkończas siędzienniki, tłum. A. Karpowicz [w:] tegoż, „Drogizeszycie...”, „drogi ekranie...”. O dziennikach osobistych, oprac. P. Rodak, Warszawa 2010. Lejeune Ph., Koronka. Dziennik jako seria datowanych śladów, przeł. M. Rodak, P. Rodak, „Pamiętnik Literacki” 2006, t. 97, z. 4.

List Romana Stanisława Ingardena do Jerzego Węgierskiego, Toruń, 9 stycznia 1985 roku, Biblioteka Zakładu Narodowego im. Ossolińskich, sygn. rps 16594/II, k. 482.

List Romana Stanisława Ingardena do Jerzego Węgierskiego, Toruń, 22 stycznia 1985 roku, Biblioteka Zakładu Narodowego im. Ossolińskich, sygn. rps 16594/II, k. 483-484. 
Listy Romana Ingardena do Ostapa Ortwina (Oskara Katzenellenbogena), oprac. S. Ukrainiec, „Pamiętnik Literacki” 1999, t. 90, z. 1.

Majewska Z., Książeczka o Ingardenie. Szkic biograficzny, Lublin 1995.

Perzanowski J. Izydora Dambska filozof nieztomny [w:] Izydora Dambska 1904 1983. Materiaty z sympozjum "Non est necesse vivere, necesse est philosophari”, Kraków, 18-19 grudnia 1998 r., oprac. J. Perzanowski, Kraków 2001.

Rodak P., Dziennik osobisty jako praktyka piśmienna: dziatanie, materialność, tekst [w:] Antropologia pisma. Od teorii do praktyki, red. Ph. Artières, P. Rodak, Warszawa 2010, s. 175-192.

Rodak P., Puste miejsca w dzienniku Marii Dąbrowskiej [w:] (Nie)obecność. Pominięcia i przemilczenia $w$ narracjach XX wieku, red. H. Gosk, B. Karwowska, Warszawa 2008, s. 456-481.

Romana Ingardena spojrzenie na Toruń ( $z$ listów do K. Twardowskiego), oprac. R. Jadczak, „Przegląd Artystyczno-Literacki” 1995, nr 6.

Spór o prawdę istnienia. Listy Edith Stein do Romana Ingardena, tłum. M. Klentak-Zabłocka, A. Wajs, Kraków-Warszawa 1994.

Tatarkiewicz W., Dzienniki, t. 1: Lata 1944-1960, oprac. R. Kuliniak, D. Leszczyna, M. Pandura, Ł. Ratajczak, Kęty 2019.

Twardowski K., Dzienniki. Cz. 1, 1915-1927, oprac. R. Jadczak, WarszawaToruń 1997.

Twardowski K., Dzienniki. Cz. 2, 1928-1936, oprac. R. Jadczak, WarszawaToruń 1997.

Twardowski K., Dzienniki mtodzieńcze (1881-1887). Uzupetnione „Dziennikiem” Marii Gasowskiej (1881), wierszami wiedeńskimi (1882) oraz korespondencja z rodzicami (1882-1893), Józefem Krypiakiewiczem (1885-1886) i Wojciechem Dzieduszyckim (1885-1891), oprac. A. Brożek, Warszawa 2013.

Ulicka D., Granice literatury i pogranicza literaturoznawstwa. Fenomenologia Romana Ingardena w świetle filozofii lingwistycznej, Warszawa 1999.

Witkiewicz S.I., Ingarden R.W., Korespondencja filozoficzna, oprac. B. Michalski, Warszawa 2002.

Zimand R., Diarysta Stefan Ż., Wrocław-Warszawa-Kraków 1990. 